\title{
Bacteriological quality of cage-cultured abalone Haliotis asinina
}

\author{
Jhonamie A. MABUHAY-OMAR, Genese Divine B. CAYABO, Lota A. CREENCIA
}

Cite this article as:

Mabuhay-Omar, J.A.,Cayabo, G.D.B. Creencia, L.A. (2021). Bacteriological quality of cage-cultured abalone Haliotis asinina. Aquatic Research, 4(2), 151-159. https://doi.org/10.3153/AR21012

\section{${ }^{1}$ College of Fisheries and Aquatic Sciences, Western Philippines University-Puerto Princesa Campus, Sta. Monica, Puerto Princesa City, Palawan, Philippines}

\section{ORCID IDs of the author(s):}

J.A.M.O. 0000-0002-8384-4449 G.D.B.C. 0000-0001-8038-0485 L.A.C. 0000-0002-8586-8604

Submitted: 06.08.2020

Revision requested: 14.09 .2020

Last revision received: 29.10 .2020

Accepted: 29.10 .2020

Published online: 07.02.2021

\section{ABSTRACT}

Abalone is one of the most highly priced seafood delicacies and prepared in various dishes like breaded, soup, steamed and sashimi. They are susceptible to microbial contamination since it is eaten raw sometimes and pathogenic microorganisms can be hazardous to consumers. The present study was carried out to determine the coliform load and the presence of presumptive pathogenic bacteria in cage-cultured abalone in Taytay, Palawan, Philippines. The study was limited to the detection of coliform and some presumptive pathogenic bacteria in different parts of abalone such as gut, gills and mantle. The result of the study revealed that the count of coliforms present in the mantle and gills of abalone falls within the normal standard limit ( $7-21 \mathrm{MPN} 100 \mathrm{~g}^{-1}$ sample). On the other hand, the gut of abalone was beyond the standard limit (460 MPN $100 \mathrm{~g}^{-1}$ sample). Moreover, the gut of abalone harbors Vibrio spp., Salmonella spp. and Shigella spp. and general enteric bacteria. Foodborne infections caused by Vibrio, Salmonella and Shigella are common in Asia.

Keywords: Abalone, Cage culture, Coliform, Microbial load, Most probable number, Salmonella, Vibrio

Correspondence:

Jhonamie A. MABUHAY-OMAR

E-mail: ihonamie.omar@wpu.edu.ph

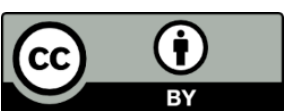

(C) 2021 The Author(s) 


\section{Introduction}

Seafood is one of the most important food components for many people particularly those in coastal communities worldwide (Edun et al., 2016; Bakr et al., 2011). Marine products such as fish and other organisms are not only the cheapest sources of protein but also a significant foreign exchange earner in global trade for a number of countries in the world (Yagoub \& Ahmed, 2003). One of the most important fishery products is abalone, a marine vetigastropod that contributes a comparatively low fraction in aquaculture production but considered as one of the most highly priced seafoods worldwide (Cook, 2016). They are marketed as live (US\$15US\$200 $\mathrm{kg}^{-1}$ ), dried (US\$156 $\mathrm{kg}^{-1}$ ), frozen (US\$5.5-US\$180 $\mathrm{kg}^{-1}$ ), canned (US\$12-US\$75 $\mathrm{can}^{-1}$ ) and steak (US\$180 kg-1) (Encena \& Bayona, 2010). Countries like China, Hong Kong, Japan, Singapore, Taiwan, Malaysia and USA are the leading importers of abalone products (FAO, 2016).

Abalone is of great importance as food because of its high nutritive value containing Vitamin E (Alpha Tocopherol), Vitamin B12, Iron, Magnesium and Phosphorus as well as bioactive compounds that are antioxidant, anti-thrombotic, anti-inflammatory, antimicrobial and anti-cancer activities (Suleria et al., 2017). However, abalone can be contaminated by various pathogens if the environment is polluted and contaminated during harvesting and handling. The contaminants may include Vibrio species, a known foodborne pathogen which are naturally occurring in marine environment and Escherichia coli and Salmonella spp. which are found in water polluted by sewage (Gnanambal \& Patterson, 2005; Chinnadurai et al., 2020).

Consumption of the shellfish which are contaminated by pathogens may cause disease or intoxication to the consumers. Vibrio cholerae causes the third-highest number of shellfish-related illnesses, after noncholera Vibrio spp. On the other hand, the occurrence of Salmonella infections due to seafood consumption is still low compared with salmonellosis associated with other foods (Sanjee \& Karim, 2016). Despite this fact, detection of Salmonella spp. in seafood should be included as it is responsible for most of the foodborne diseases or gastroenteritis characterized by diarrhea, abdominal cramp, vomiting, nausea, and fever. The Centers for Disease Control and Prevention (CDCP) declared that Salmonella is the foremost causative agent of bacterial foodborne diseases resulting in approximately 1.4 million nontyphoidal illnesses, 15,000 hospitalizations, and 400 deaths in the USA annually (Sanjee \& Karim, 2016). In addition, fecal coliforms such as $E$. coli are used as monitoring tool of the quality of shellfish- growing waters and bivalve molluscs. There is a need for additional methods to lower coliform aerobic mesophilic count in culture areas and in harvested shellfish (Martinez et al., 2009).

Abalone is prepared in various highly priced dishes like breaded, soup, steamed and sashimi. Abalone is susceptible to microbial contamination and since it is sometimes eaten raw (Surtida, 2000), pathogenic microorganisms can be hazardous to consumers. Thus, this study was conducted to determine the coliform load and the presence of presumptive pathogenic bacteria such as Vibrio, Salmonella, Shigella, and general enteric bacteria in different body parts of cage-cultured abalone. This study showed which part of the abalone is safe to consume raw and which part must be removed or cooked before consumption.

\section{Material and Methods}

\section{Collection of Samples}

Thirty samples of adult cage-cultured abalone $H$. asinina (30$35 \mathrm{~mm}$ ) were collected from Pamantolon, Taytay, Palawan, Philippines (Figure 1) in September 2018. Collection was only done once. The abalone was cultured in floating bamboo cages along the lines of farmed seaweed. The site is near a populated area where majority of the houses are made up of indigenous materials. The average water temperature, salinity and $\mathrm{pH}$ of the area were $28^{\circ} \mathrm{C}, 30 \mathrm{ppt}$ and 6.5 , respectively. Abalone samples were carefully handpicked from the cages while riding a motorless boat. The collected samples were placed in sterile cooler box and were transported live to the Microbiology Laboratory of the Western Philippines University-Puerto Princesa Campus for microbial examination. Upon arrival, the abalone samples were cleaned by immersing it in sterile seawater for 5 minutes followed by another 10 minutes in cold sterile distilled water at $4-6^{\circ} \mathrm{C}$ to relax the organisms.

\section{Sample Preparation for Microbial Analysis}

The abalone samples were soaked in $55^{\circ} \mathrm{C}$ sterile distilled water. The shell and meat were separated before dissection. Different body parts of abalone; gills (G), foot mantle (M) and the gut (D) were aseptically separated and extracted using sterile dissection tools inside a laminar flow. Ten grams of each of the abalone body parts was blended with $90 \mathrm{~mL}$ of sterile distilled water to dilute and to homogenize. The samples of the body parts were processed fresh to maximize inventory of viable organisms. 


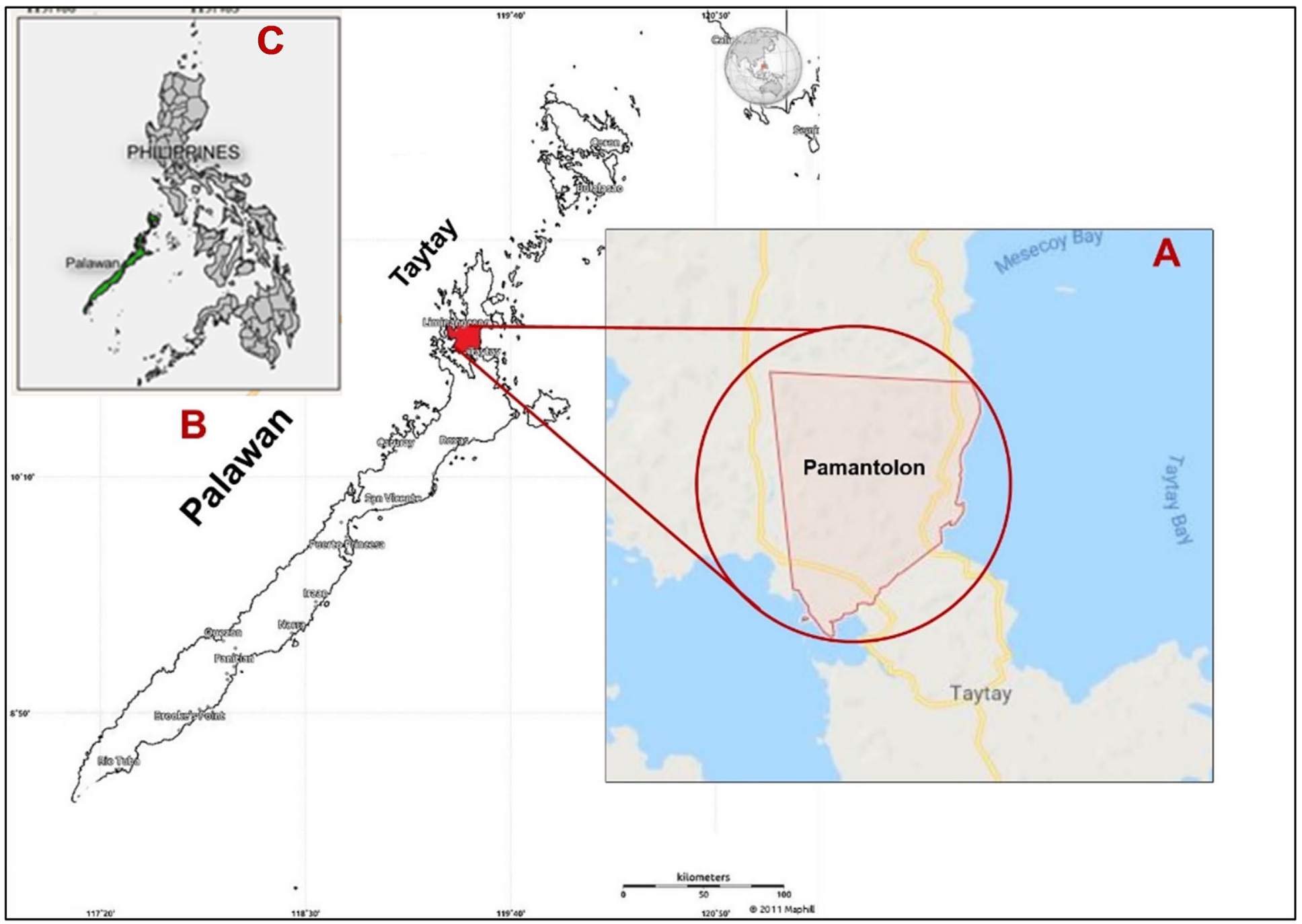

Figure 1. Map showing the site of abalone culture in Pamantolon, Taytay (A), Palawan (B). Philippines (C)

\section{Coliform Detection (MPN Method)}

The number of coliform in the samples was determined using the conventional three-tube MPN (most probable number) method (Brown, 2005). Ten $\mathrm{mL}$ of the homogenized sample was added in test tube containing $10 \mathrm{~mL}$ volume of double strength lactose broth (DSLB). One $\mathrm{mL}$ and $0.1 \mathrm{~mL}$ of the sample were added separately in test tube containing $10 \mathrm{~mL}$ volume of single strength lactose broth (SSLB). The total sets of tubes were incubated at $35^{\circ} \mathrm{C}$ for $24 \mathrm{~h}$ and examined for the presence of growth accompanied by gas production. Those cultures positive for gas formation were inoculated into Eosin Methylene Blue (EMB) agar and were incubated at $35^{\circ} \mathrm{C}$ for $24 \mathrm{~h}$. After incubation, EMB Agar plates were examined. Escherichia coli colonies grow with a metallic sheen with a nucleated center, Aerobacter aerogenes colonies have a brown center, and nonlactose-fermenting Gram- negative bacteria appear pink. A loopful of sample from positive EMB agar were inoculated in DSLB tubes and incubated for $24 \mathrm{~h}$. at $35^{\circ} \mathrm{C}$. Gram staining followed for verification. Quantification was done using the standard MPN table and coliform was reported as MPN $100 \mathrm{~g}^{-1}$ sample.

\section{Enumeration of Presumptive Pathogenic Bacteria}

The pour-plate method was used in this study as adopted from the study of Sanders (2012). Different selective culture media were used to enumerate presumptive pathogenic bacteria from cage-cultured abalone $H$. asinina. The Thiosulfate Citrate Bile Salts Sucrose (TCBS) was used for total Vibrio species, Salmonella-Shigella (SS) agar for total Salmonella and Shigella species and McConkey agar for total enteric bacteria. Each medium was prepared according to the suggested ratio and proportion of the manufacturer found in the labels. One $\mathrm{mL}$ of each previously homogenized sample was added 
to the prepared medium, mixed gently, and poured into the petri dish and allowed to solidify. There were three replicates prepared for each body part and each selective culture medium. All plates with different culture media were incubated at $35^{\circ} \mathrm{C}$ for 24 hours. After incubation, all plates were examined. Colonies growing on each plate were examined for individual characteristics, counted as colony forming units (CFU) and recorded. Rapid lactose fermenting colonies such as $E$. coli appear pink in color on MacConkey agar. Colonies of Salmonella species appear red with black centers while Shigella species are red to pink colonies without black center on SS agar. Vibrio colonies appear yellow and green on TCBS agar.

\section{Statistical Analyses}

The data on the number of presumptive pathogenic bacteria at different parts of abalone were analyzed using one-way analysis of variance (ANOVA) to test the significant differences. The data were subjected to Post hoc test (Tukey's Test) to compare the means $(\mathrm{p}<0.05)$.

\section{Results and Discussion}

Samples from different body parts of abalone showed gas formations after $24 \mathrm{~h}$ of incubation in multiple tube test indicating the presence of gas-forming lactose fermenters which implied the presence of coliform bacteria. When confirmation test was done, it was confirmed that the coliform present in this study was E. coli. Results of this study showed that the gut of abalone exceeded the acceptable limit of $E$. coli for shellfish with a count of 460 MPN $100 \mathrm{~g}^{-1}$ (Table 1). The acceptable limit of $E$. coli for shellfish is $230 \mathrm{MPN} 100 \mathrm{~g}^{-1}$ based on several references enumerated in Table 1. Escherichia coli is frequently used as an indicator of fecal contamination because it lives naturally in human feces and can survive in water (Duncan et al., 2009). The high level of E. coli in the gut could be due to the probable high count of fecal coliforms in their growing water areas. It was observed that the culture areas in Pamantolon, Taytay were surrounded by houses built with low-cost materials with comfort rooms that don't have septic tank and very near the shore so runoff from terrestrial area could have contributed to the presence of coliforms. Chinnadurai et al. (2020) proved that bacterial concentrations in shellfish correlate strongly with those in the waters. Their sampling sites (growing sites of shellfish) receive high levels of contaminants from drainage channels, open toilet drain, non-functional septic tank and livestock production areas, and they found similar high contamination in the shellfish from the areas. Another study examined the concentration of coliforms in oysters in the River Blackwater Estuary in the UK where they found that the main source of E. coli and Streptococci to the oyster beds are sewage and agricultural sources, respectively (Florini et al., 2020).

Microorganisms that can be found in marine environment and most commonly encountered by marine species are free-living forms found in water and sediment and rarely include any species of mammalian pathogens (ICMSF, 1986). Hence, fish and shellfish that are handled properly during harvest from waters not polluted by human or animal wastes are often free from intrinsic microbiological hazard. Fish and other marine animals do not usually carry Escherichia coli, the 'fecal coliforms', and enterococci as these microorganisms are generally considered to be typical mammalian microflora. The presence of human enteric organisms on marine food products is clear evidence of contamination from a terrestrial source (ICMSF, 1986). It is important to understand the origin of fecal contamination in shellfish farms to assess the associated health risks as well as the actions needed to address the problem (Florini et al., 2020). In addition, since the abalone samples of this study were also cultured along the lines of farmed seaweeds, the water current and mixing may be obstructed resulting in possible accumulation of microorganisms around the area. On the other hand, the gills and mantle of the abalone had $E$. coli number lower than the microbial limit for shellfish. This is reassuring to note as the part of abalone mostly consumed is the mantle.

Table 1. Most probable number (MPN) of coliform bacteria present in different parts of adult abalone Haliotis asinina and the microbial limit (Escherichia coli) for shellfish based on European Communities (EC) (2007) and Philippine National Standards - Bureau of Agriculture and Fisheries Product standards (PNS-BAFPS) (2011).

\begin{tabular}{ccc}
\hline Sample & $\begin{array}{c}\text { E. coli } \\
\text { MPN/100g }\end{array}$ & Microbial Limit \\
\hline Gut & 460 & $230 \mathrm{MPN} / 100 \mathrm{~g}$ according to PNS-BAFPS (2011) \\
Gills & 21 & and EC (2007) \\
Mantle & 7 & \\
\hline
\end{tabular}


The presence of E. coli in food or water implies that there could be other pathogens present like Klebsiella and Vibrio and other clinically important bacterial pathogen (WHO, 2001). In this study, presumptive pathogenic bacteria were detected in different body parts of abalone. The analysis of variance (ANOVA) proved that there were significant differences in the number of presumptive pathogenic bacteria $(\mathrm{p}<$ 0.05 ) at different parts of abalone. Tukey's test showed that the total enteric bacteria had the highest number in the gills of abalone with a count of $29 \mathrm{CFU} \mathrm{g}^{-1}$ sample followed by Salmonella-Shigella and then Vibrio (Figure 2). In the gut, ANOVA proved significant differences among the different groups of presumptive pathogenic bacteria and Tukey's test showed that Vibrio and enteric bacteria were higher in terms of total number of colonies with a count of $101 \mathrm{CFU} \mathrm{g}^{-1}$ sample and $93 \mathrm{CFU} \mathrm{g}{ }^{-1}$ sample respectively, than the number of Salmonella and Shigella (Figure 2). On the other hand, Vibrio was found to be significantly highest in the mantle with 22 $\mathrm{CFU} \mathrm{g}^{-1}$ (Figure 2). Among the three body parts of abalone that were tested, the gut harbors the highest number of presumptive pathogenic bacteria. In addition, the Vibrio group had the highest number found in abalone. According to PNSBAFPS (2011), Salmonella species should be absent in $25 \mathrm{~g}$ sample and Vibrio should not exceed 100 MPN/100g sample.

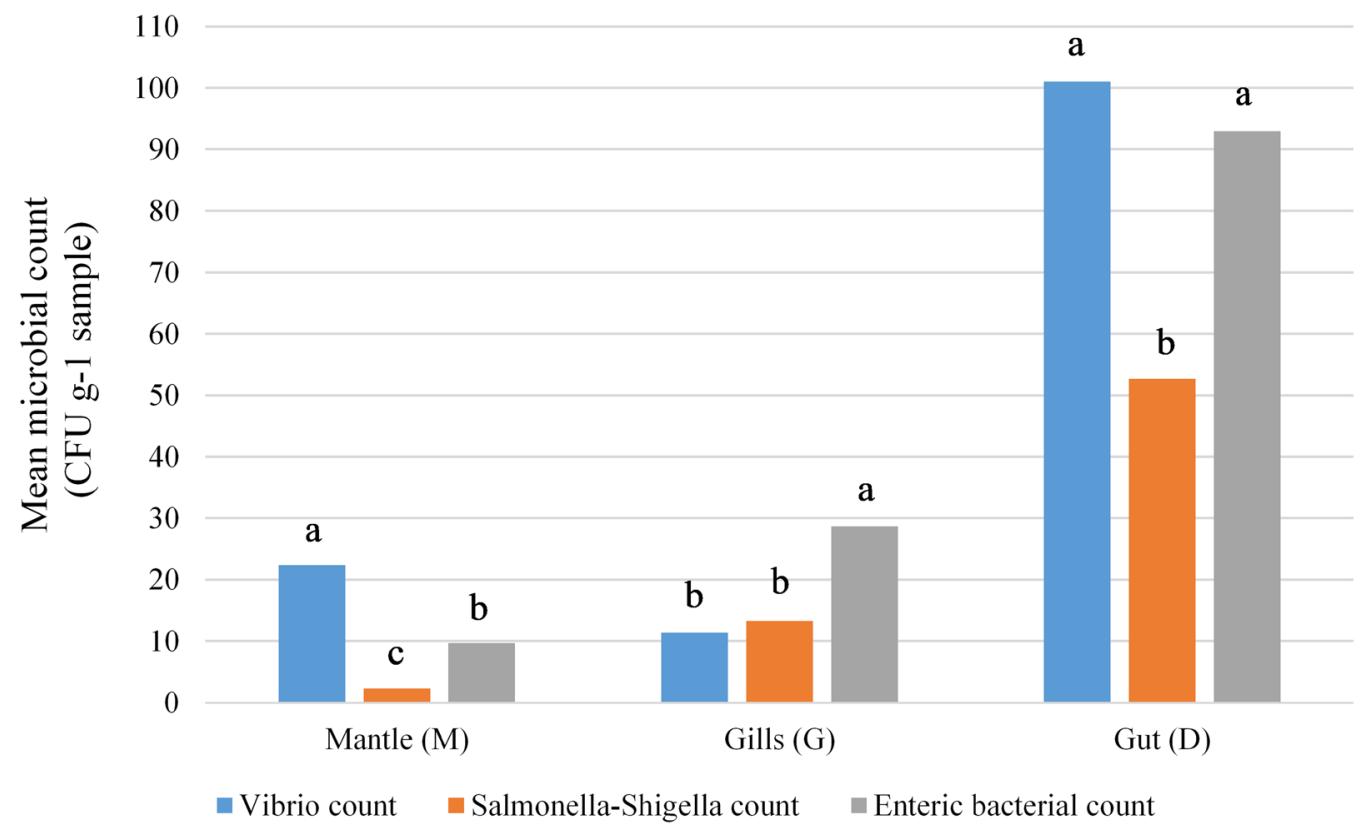

Figure 2. Mean microbial count of presumptive pathogenic bacteria from the gills, gut and mantle of adult cage-cultured abalone Haliotis asinina Linn. Different letters signify significant differences at $\mathrm{p}<0.05$.

The outbreak of seafood infections from contaminated waters are caused by variety of bacteria, viruses and parasites have been reported worldwide (Florini et al., 2020). Centers for Disease Prevention and Control (CDC) reported to the Foodborne Disease Outbreak Surveillance System (FDOSS) 188 outbreaks of seafood-associated infections, causing 4,020 illnesses, 161 hospitalizations, and 11 deaths from 1973 to 2006. A total of $76.1 \%$ of these seafood-associated outbreaks were due to a bacterial agent (CDC, 2010). It was recorded that Vibrio and Salmonella were the most commonly reported bacteria that cause seafood contamination outbreaks (Iwamoto et al., 2010).

Salmonella species is one of the most important food-borne pathogens and have been detected in seafoods (Edun et al., 2016). In this study, Salmonella was present in the mantle, gills and gut of abalone. This species can cause wide range of illness. Example is the common typhoid fever caused by Salmonella typhi with common symptoms of fever, headache, malaise, anorexia and red spots on the trunk (WHO, 1996). In Brazil, the absence of Salmonella spp. in $25 \mathrm{~g}$ of oyster flesh is required (Brazilian Regulations, 2019). Similar microbial limit in Salmonella spp. is also imposed in the Philippines by PNS-BAFPS (2011). In the study conducted by Lameira Silva et al. (2020), Salmonella spp. was present in the flesh of oyster in all sampling sites in Amazon estuaries in Pará, Brazil irrespective of the seasonal period. In contrast, the study conducted by Sorio and Peralta, (2018) revealed that Salmonella spp. was not detected in any samples of oysters growing in selected production areas in Dumangas, Iloilo, Philippines. Similar result was presented by Martinez et al. (2009) wherein all molluscan shellfish samples (mussel, 
clams and cockles) in their study were negative for the presence of genes encoding virulence factors in Salmonella. Another study was conducted in South Korea to analyze the microbiota of abalone to improve awareness on outbreaks and causes of food poisoning and to help the management of seafood products (Lee et al., 2016). In this study, there were over 2700 species of microorganisms detected in the samples but only five species were potentially pathogenic and did not include either Salmonella or Vibrio species.

Vibrio species are problems in molluscan shellfish hatcheries including abalone (Lee et al., 2001; Handlinger et al., 2005; Kua et al., 2011). According to Romalde et al. (2014), Vibrio parahaemolyticus, $V$. harveyi, $V$. splendidus, V. aglinolyticus, $V$. anguillarum and $V$. vulnificus (Lee et al., 2001; Handlinger et al., 2005; Cai et al., 2006; Pitchon et al., 2013) are major species infecting abalone species. Aside from outbreaks of diseases caused by Vibrio species that leads to mass mortalities and economic losses in cultured species, they are also associated with live seafood as they form part of the indigenous microflora of the marine environment. Foodborne infections caused by Vibrio spp. are common throughout the world so proper precautionary measures are also important (FAO \& WHO, 2020). In the USA, consumption of raw oysters with contamination of $V$. vulnificus and $V$. parahaemolyticus causes septicemia and other infection (FAO \& WHO, 2005). In Japan, $V$. parahaemolyticus infections results from consumption of raw seafoods (FAO \& WHO, 2011). On the other hand, bacterial infection is low in Thailand and other Southeast Asian countries including Philippines because shellfish are generally consumed after cooking (FAO \& WHO, 2011). Although in one particular event in Cebu City, Philippines, $V$. parahaemolyticus has been linked to fish and shellfish contamination causing foodborne disease wherein 97 people were hospitalized (Borromeo, 2007). This bacterium is a common cause of bloody diarrhea, abdominal cramps, nausea, vomiting, and fever worldwide that occur about 4-96 h from the time of ingestion (FSIS, 2014). Undercooking could explain the presence of Vibrio in fish and shellfish commodities that leads to infection and disease (FAO \& WHO, 2020). On the other hand, some countries like Japan, France, Australia, New Zealand, China and Taiwan isolated several species of Vibrio such as V. campbellii, V. harveyi, $V$. parahaemolyticus, $V$. alginolyticus and $V$. splendidus from different species of Haliotis where these Vibrio species caused mass mortality in cultured abalone (Bower, 2017).

In this study, results showed that most of the pathogenic bacteria were found in the gut of abalone. This result supports the previous studies (Mabuhay-Omar et al., 2019; Santiago \& Mabuhay-Omar, 2019) wherein the gut of abalone harbored the highest number of microorganisms compared to gills and mantle. Mantle is the part of abalone usually consumed by human and so it is good to note that the number of microorganisms is very small compared to the maximum limit but since fecal coliform and some presumptive pathogenic bacteria are present, it is important to depurate and properly prepare the abalone before eating. The presence of fecal coliform and presumptive pathogenic bacteria in the mantle of abalone can be due to contamination during handling and lack of proper cleaning protocol. In addition, removal of gut and gills of abalone before cooking or preparing uncooked menu is needed since presumptive pathogenic microorganisms are found in these parts of abalone.

\section{Conclusion}

This study proved the presence of coliform such as E. coli and some presumptive pathogenic microorganisms in abalone such as Salmonella, Shigella, Vibrio and total enteric bacteria. With this information, it is recommended for the abalone farmers to optimize the culture management practices such as monitoring of the physico-chemical parameters of water since the presumptive pathogenic bacterial species detected are also opportunistic pathogens and could cause massive losses in abalone production under favorable conditions. Also, these species are considered to be human pathogens and could cause various infections among human population. It is also important to properly cook the abalone before eating. In addition, removal of gut and gills of abalone before preparing uncooked menu is needed since microorganisms are found in these parts of abalone. Prior to selling cultured abalone to consumers, depuration methods may be applied to minimize possible contamination.

\section{Compliance with Ethical Standard}

Conflict of interests: The authors declare that for this article they have no actual, potential or perceived conflict of interests.

Ethics committee approval: This work does not require ethic permissions.

Funding disclosure: This study was funded by the Commission on Higher Education (CHED DARE TO) of the Philippines as approved by the Board of Regents (BOR) under the Resolution No. 325 , series of 2017.

\section{Acknowledgments: -}

Disclosure: - 


\section{References}

Bakr, W.M.K., Hazzah, W.A., Abaza, A.F. (2011). Detection of Salmonella and Vibrio species in some seafood in Alexandria. Journal of American Science, 7(9), 663-668.

Borromeo, R.U. (2007). City health says grilled squid caused summit food poisoning. The Freeman. Retrieved from http://www.philstar.com/cebu-news/383788/city-healthsays-grilled-squid-caused-summit-food-poisoning on 19 Oct 2020 (accessed 10.112020 ).

Bower, S.M. (2017). Synopsis of Infectious Diseases and Parasites of Commercially Exploited Shellfish: Bacterial Diseases of Abalone. https://www.dfo-mpo.gc.ca/science/aahsaa/diseases-maladies/vibrioab-eng.html (accessed 10.11 2020).

Brazilian Regulations. (2019). Technical regulation on microbiological standards for foods. Resolution - RDC No. 331. Ministry of Health, National Health Surveillance Agency,

Brown, A.E. (2005). Benson's Microbiological Applications Complete Version: Laboratory Manual in General Microbiology, 9th ed. Mac Graw Hill Companies, Inc. N.Y.

Cai, J., Han, Y., Wang, Z. (2006). Isolation of Vibrio parahaemolyticus from abalone (Haliotis diversicolor supertaxa L.) postlarvae associated with mass mortalities. Aquaculture, 257, 161-166.

https://doi.org/10.1016/j.aquaculture.2006.03.007

Centers for Disease Control and Prevention (CDC). (2010). Preliminary foodnet data on the incidence of infection with pathogens transmitted commonly through food. Morbidity and Mortality Weekly Report, 59 (14), 418-422.

Chinnadurai, S., Campos, C.J.A., Geethalakshmi, V., Sharma, J., Kripa, V., Mohamed, K.S. (2020). Microbiological quality of shellfish harvesting areas in the Ashtamudi and Vemband estuaries (India): Environmental influences and compliance with international standards. Marine Pollution Bulletin, 156, 1-9.

https://doi.org/10.1016/j.marpolbul.2020.111255

Cook, P.A. (2016). Recent trends in worldwide abalone production. Journal of Shellfish Research, 35(3), 581-583.

https://doi.org/10.2983/035.035.0302

Duncan, P.F., Andalecio, M.N., Peralta, E., Laureta, L., Hidalgo, A.R., Napata, R. (2009). Evaluation of production technology, product quality and market potential for the development of bivalve mollusc aquaculture in the Philippines. Australian Centre for International Agricultural Research (ACIAR), $193 \mathrm{pp}$.

Edun, O.M., Akinrotimi, O.A., Makinde, O.O. (2016). Seasonal changes of microbial load in some sea foos from Baguma and Ekerekana Creeks, Niger Delta, Nigeria. Peertechz Journal of Environmental Science and Toxicology, 1(1), 001-007.

https://doi.org/10.17352/aest.000001

Encena, II V.C., Bayona, N.C. (2010). Farming of the tropical abalone Haliotis asinina. Aquaculture Extension Manual, 49, 1-24.

European Communities (EC). (2007). Commission regulation no. 1441/2007 of December 2007 amending regulation (EC) no. 2073/2005 on microbiological criteria for foodstuffs. Official Journal of the European Union, 322, 12-29. http://data.europa.eu/eli/reg/2007/1441/oj

Florini, S., Shahsavari, E., Ngo, T., Aburto-Medina, A., Smith, D.J., Ball, A.S. (2020). Factors influencing the concentration of fecal coliforms in oysters in the River Blackwater Estuary, UK. Water, 12, 1-12.

https://doi.org/10.3390/w12041086

Food Safety Inspection Service (FSIS) (2014). Foodborne Illness: What Consumers Need to Know. Washington, DC: United States Department of Agriculture. Retrieved from http://www.fsis.usda.gov/wps/portal/fsis/topics/food-safetyeducation/get-answers/food-safety-fact-sheets/foodborne-illness-and-disease/foodborne-illness-what-consumers-needto-know/CT_Index on 16 Oct 2020.

Food and Agriculture Organization (FAO) (2016). The State of World Fisheries and Aquaculture. Contributing to food security and nutrition for all. Rome. 200 pp. ISBN 97892-5-109185-2.

Food and Agriculture Organization (FAO), World Health Organization (WHO) (2020). Risk assessment tools for Vibrio parahaemolyticus and Vibrio vulnificus associated with seafood. Microbiological Risk Assessment Series No. 20. Rome.

Food and Agriculture Organization (FAO), World Health Organization (WHO) (2011). Risk assessment of Vibrio parahaemolyticus in seafood: Interpretative summary and 
Technical report. Microbiological Risk Assessment Series, No 16, Rome.

Food and Agriculture Organization (FAO), World Health Organization (WHO) (2005). Risk assessment of Vibrio vulnificus in raw oysters: Interpretative summary and Technical report. Microbiological Risk Assessment Series, No 8, Rome.

Food Drugs Administration (FDA). (2009). National Shellfish Sanitation Program guide for the control of molluscan shellfish 2007 revisions. Retrieved from http://www.cfsan.fda.gov/;ear/nss4-toc.html (accessed 10.11 2017)

Gnanambal, K., Patterson, J. (2005). Biochemical and microbiological quality of frozen fishes available in Tuticorin supermarkets. Fishery Technology, 42(1), 83-84.

Handlinger, J.J., Donachie, C.L., Gabor, L., Taylor, D. (2005). Bacterial infection in Tasmanian farmed abalone: Causes, pathology, farm factors and control options. Diseases of Asian Aquaculture, 5, 289-299.

International Commission of Microbiological Specification for Food (ICMSF). (1986). Microorganisms in foods. Vol. 1: Their significance and methods of enumeration. 2nd edition, Thatcher F. S., Clark D. S. (eds), University of Toronto Press, Toronto, ON, Canada, pp. 19-30, 181.

Iwamoto, M., Ayers, T., Mahon, B.E., Swerdlow, D.L. (2010). Epidemiology of seafood-associated infections in the United States. Clinical Microbiology Reviews, 23(2), 399411.

https://doi.org/10.1128/CMR.00059-09

Kua, B.C., Ramly, R., Devakie, M., Groman, D., Berthe, C.J.F. (2011). Investigating a mortality in hatchery cultured tropical abalone, Haliotis asinina Linnaeus, 1758 in Malaysia. Diseases of Asian Aquaculture, 7, 103-109.

Lameira Silva, O.L., Veríssimo S.M.M., da Rosa, A.M.B.P., Iguchi, B.Y., Nunes, E.D.S.C.D.L., Moraes, C.M.D., Cordeiro, C.A.M., Xavier, D.D.A., Pinto, A.S.O., Peixoto Joele, M.R.S., Brito, J.D.S., Juen, L., Rocha, R.M.D. (2020). Effects of environmental factors on microbiological quality of oyster farming in Amazon estuaries. Aquaculture Reports, 18, 1-10.

https://doi.org/10.1016/j.aqrep.2020.100437
Lee, K.K., Liu, P.C., Chen, Y.C., Huang, C.Y. (2001). The implication of ambient temperature with the outbreak of vibriosis in cultured small abalone Haliotis diversicolor supertaxa Lischke. Journal of Thermal Biology, 26, 585-587. https://doi.org/10.1016/S0306-4565(01)00004-3

Lee, M. J., Lee, J. J., Chung, H. Y., Choi, S. H., Kim, B. S. (2016). Analysis of microbiota on abalone (Haliotis discus hannai) in South Korea for improved product management. International journal of food microbiology, 234, 45-52. https://doi.org/10.1016/j.ijfoodmicro.2016.06.032

Mabuhay-Omar, J.A., Cayabo, G.D.B., Nuñala, I.J.P., Habal, S.E., Creencia, L.A. (2019). Microbial and microparasite abundance in cage-cultured abalone Haliotis asinina. Journal of Shellfish Research, 38(2), 405-411. https://doi.org/10.2983/035.038.0223

Martínez, O., Rodríguez-Calleja, J.M., Santos, J.A., Otero, A., García-López, M.L. (2009). Foodborne and indicator bacteria in farmed molluscan shellfish before and after depuration. Journal of Food Protection, 72(7), 14431449.

https://doi.org/10.4315/0362-028x-72.7.1443

Philippine National Standards - Bureau of Agriculture and Fisheries Product standards (PNS-BAFPS). (2011). Philippine National Standards - Bureau of Agriculture and Fisheries Product Standards for Live and Raw Molluscs. PNS/BAFPS 89:2011, ICS 67.120.30.

Pitchon, D., Cudennec, B., Huchette, S., Djediat, C., Renault, T., Paillard, C., Auzoux-Bordenave, S. (2013). Characterization of abalone Haliotis tuberculata-Vibrio harveyi interactions in gill primary cultures. Cytotechnology, 65, 759-772.

https://doi.org/10.1007/s10616-013-9583-1

Romalde, J.L., Diéguez, A.l., Lasa, A., Balboa, S. (2014). New Vibrio species associated to molluscan microbiota: a review. Frontiers in Microbiology, 4, 1-11.

https://doi.org/10.3389/fmicb.2013.00413

Sanders, E.R. (2012). Aseptic laboratory techniques: Plating methods. Journal of Visualized Experiments, 63, 1-18. https://doi.org/10.3791/3064

Sanjee, S.A., Karim, M.E. (2016). Microbiological quality assessment of frozen fish and fish processing materials from Bangladesh. International Journal of Food Science, 1-6. https://doi.org/10.1155/2016/8605689 
Santiago, C.H.S., Mabuhay-Omar, J.A. (2019). Isolation and characterization of antimicrobial-producing bacteria from the donkey's ear abalone Haliotis asinina, Journal of Shellfish Research, 38(2), 413-416.

https://doi.org/10.2983/035.038.0224

Sorio, J.C., Peralta, J.P. (2018). Microbiological quality of oyster (Crassostrea iredalei) in selected production areas in Dumangas, Iloilo, Philippines. AACL Bioflux, 11(2), 319326.

Suleria, H.A.R., Masci, P.P., Gobe, G.C., Osborne, S.A. (2017). Therapeutic potential of abalone and status of bioactive molecules: A comprehensive review. Critical Reviews in Food Science and Nutrition, 57(8), 1742-1748. https://doi.org/10.1080/10408398.2015.1031726
Surtida, A.P. (2000). Abalone. SEAFDEC Asian Aquaculture, 22(4), 14-16.

World Health Organization (WHO). (2001). Water quality: Guidelines, standards and health. IWA Publishing, London, UK. ISBN: 1900222280

World Health Organization (WHO). (1996). Weekly Epidemiological Record. 73, 201-208.

Yagoub, S.O., Ahmed, T.M. (2003). Pathogenic microorganisms in freshwater samples collected from Khartoum central market. Sudan Journal of Veterinary Science and Animal Husbandry, 43, 32-37. 